\title{
Papillate Watermeal, Wolffia brasiliensis, in Eastern Ontario: An Addition to the Flora of Canada
}

\author{
E. R. THOMSON
}

P.O. Box 262, Merrickville, Ontario K0G 1N0 Canada

Thomson, E. R. 2005. Papillate Watermeal, Wolffia brasiliensis, in eastern Ontario: An addition to the flora of Canada. Canadian Field-Naturalist 119(1): 137-138.

Wolffia brasiliensis is reported from eastern Ontario, at several sites within Frontenac and Lanark Counties. This is the first published record of $W$. brasiliensis in Canada.

Key Words: Wolffia brasiliensis, Wolffia papulifera, Watermeal, range extension, new record, Ontario, Canada.

Wolffia (Watermeal) is a small genus in the Lemnaceae (Duckweed Family) which consists of about 11 species and includes the smallest known flowering plants in the world. According to Scoggan (1978), Boivin (1967), and Dore (1957) only two species occur in Canada: Wolffia columbiana Karsten (reported by Scoggan and Boivin as W. arhiza Wimm.) and W. borealis (Engelm.) Landolt (referred to as W. punctata by Scoggan, Boivin, Dore and other American authors). Both species occur, often together, in eastern Ontario (Dore 1957; Newmaster et al. 1998). A third species, $W$. brasiliensis Weddell (= W. papulifera $\mathrm{C}$. H. Thompson), has a range which extends from South America north to the eastern United States where it approaches the Canadian border (Landolt 2000). It has been found as far north as Berrien County, Michigan, and the shore of Lake Erie east of Cleveland, Ohio (Hess 1986; Dore 1957).

While conducting a botanical survey near Garter Lake, Bedford District, Frontenac County, Ontario, on 28 June 2003, I came upon a small, shallow beaver pond with Wolffia growing on the surface. The fronds of these plants were flattened on top as in $W$. borealis, but each bore a single, distinct papilla in the middle of the upper surface (Figure 1). The apex of the frond was rounded in dorsal view, matching the description of $W$. brasiliensis, rather than that of the acutely pointed $W$. borealis.

No published record of W. brasiliensis in Canada has been found. (Reports of W. brasiliensis from Ontario, including that of Kartesz (1999), are based on W. borealis (Dore 1957; Morton and Venn 1990).) As well, in the DAO herbarium (acronym according to Holmgren et al. 1990), no W. brasiliensis was detected in collections of the closely related $W$. borealis, athough, as Dore notes, it is difficult to distinguish between them in the dry state. There is, however, a single specimen there of W. brasiliensis, collected on 10 September 1964 by Isabel Bayly, which has interesting label data [DAO 717812]. Although the collection was made in the greenhouse at Carleton University, Ottawa, from "dense vigorous growth in aerated aquarium with Eichornia [sic]", the original material was said to have

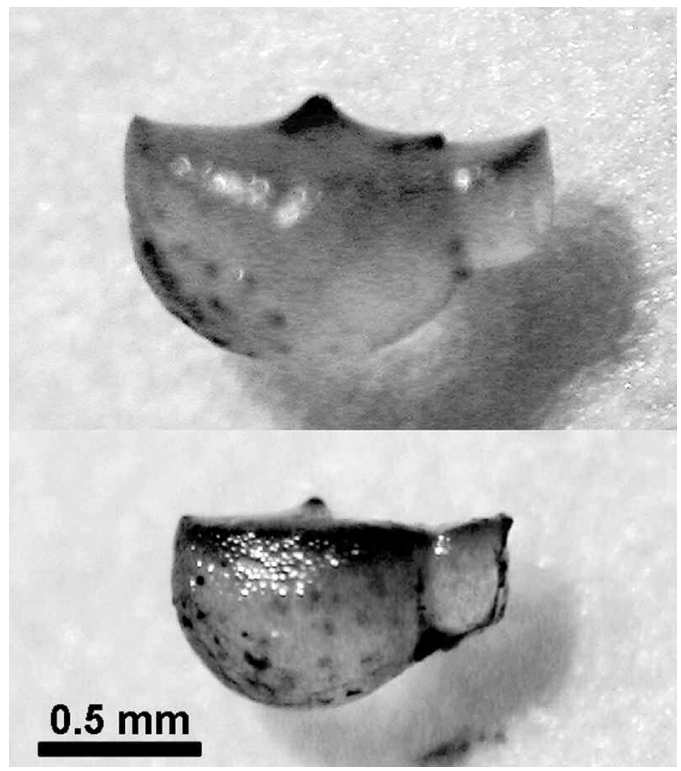

FIGURE 1. Vegetative fronds of Wolffia brasiliensis from Frontenac County, Ontario, showing central papilla. Photograph by Stephen J. Darbyshire.

come from an "artificial pond caused by a construction error, flooded 8-10 years previously", near Christie Lake, in Lanark County, Ontario. It is interesting to note that Christie Lake is only about $20 \mathrm{~km}$ from the Garter Lake site.

Situated in a predominantly deciduous forest, the Beaver pond near Garter Lake was edged with Woolgrass (Scirpus cyperinus) and Bristly Sedge (Carex comosa) and contained a variety of water plants including Watershield (Brasenia schreberi), Greater Bladderwort (Utricularia macrorhiza, Bur-reed (Sparganium americanum), and Coontail (Ceratophyllum demersum). Mixed in with the W. brasiliensis were a few plants of W. columbiana. Over the summer of 2003, the colony increased in size. Whereas on 3 July it had 
covered an area about $10 \mathrm{~m}^{2}$ of the pond's surface, by 16 September it covered an area of about $40 \mathrm{~m}^{2}$. The ratio of abundance of the two species appeared to remain fairly constant.

Further surveys produced additional findings of $W$. brasiliensis in the same general area of Frontenac and Lanark Counties (see Appendix). Six locations were checked where patches of Wolffia were present. Wolffia brasiliensis was present in five of them, and in each of these five populations, it was the predominant species. The populations were found in a variety of quiet, shallow-water habitats, including beaver ponds, cattail marshes, and an old, beaver wetland of grasses, sedges and holly. At all sites, W. columbiana was also present but in lower numbers. At both sites on Briggs Lane (collections 3 and 4), some $W$. borealis was also found mixed with the other two species. In collection 7, from 16 October, a few plants of $W$. brasiliensis were in flower. The style with its dark stigma was clearly visible protruding from the floral cavity. On some individuals, the single anther could also be seen, still within the cavity.

Has Wolffia brasiliensis spread to this area recently, or has it been growing here unnoticed for years? The Bayly collection from 1964 seems to suggest the latter. The similarity of this species to $W$. borealis could cause it to be easily overlooked. Judging from the several locations found, the farthest ones being about $20 \mathrm{~km}$ apart, it seems unlikely that it is a recent, isolated, chance introduction by waterfowl. Rather, it appears to be well established in the area.

\section{Acknowledgments}

I am indebted to Stephen Darbyshire of Agriculture and Agri-Food Canada, who provided encouragement and generous assistance in many ways, including preparing the herbarium specimens, photographing the plants, locating reference material, and reviewing of the manuscript.

\section{Literature Cited}

Boivin, B. 1967. Énumération des plantes du Canada. VI Monopsides, ( ${ }^{\circ}$ me partie). Le Naturaliste Canadien 94: 471-528.

Dore, W. G. 1957. Wolffia in Canada. Canadian Field-Naturalist 71: 10-16.

Hess, W. J. 1986. Wolffia papulifera Thompson (Lemnaceae), new to Michigan. Sida 11: 407-411.

Holmgren, P. K., N. H. Holmgren, and L. C. Barnett. 1990. Index Herbariorum. Part I: The Herbaria of the World. $8^{\text {th }}$ edition. New York Botanical Garden, Bronx, New York. 693 pages.

Kartesz, J. T. 1999. A Synonymized Checklist and Atlas with Biological Attributes for the Vascular Flora of the United States, Canada, and Greenland. First edition. in: Kartesz, J. T., and C. A. Meacham. Synthesis of the North American Flora, version 1.0. North Carolina Botanical Garden, Chapel Hill, North Carolina.

Landolt, E. 2000. 204. Lemnaceae Gray. Duckweed Family. Pages 143-153 in Flora of North America North of Mexico. Volume 22. Edited by Flora of North America Editorial Committee. Oxford University Press, New York, New York.

Morton, J. K., and J. M. Venn. 1990. A Checklist of the Flora of Ontario, Vascular Plants. Department of Biology, University of Waterloo, Waterloo, Ontario.

Newmaster, S. G., A. Lehela, P. W. C. Uhlig, S. McMurray, and M. J. Oldham. 1998. Ontario Plant List. Forest Research Information Paper Number 123, Ontario Forest Research Institute, OMNR, Sault Ste. Marie, Ontario.

Scoggan, H. J. 1978. The Flora of Canada Part 2 - Pteridophyta, Gymnospermae, Monocotyledoneae. National Museum of Natural Sciences Publications in Botany, Number 7: 93-545. National Museums of Canada, Ottawa, Ontario.

Received 8 November 2003

Accepted 23 February 2005

\section{APPENDIX}

Collections of Wolffia brasiliensis from Ontario deposited in the herbarium of Agriculture and Agri-Food Canada, Ottawa (DAO).

1. Frontenac County, Bedford District, Garter Lake, UTM: 18T 03771734941383 [44³7'02"N, 76³2'53"W]; growing in a small, shallow beaver pond on stream flowing into Garter Lake; E. R. Thomson, 3 July 2003 (DAO 792125)

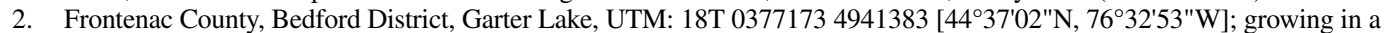
small, shallow beaver pond on stream flowing into Garter Lake; E. R. Thomson, 12 July 2003 (DAO 792123)

3. Frontenac County, Bedford District, west of Wolfe Lake, Briggs Lane, UTM: 18T 03796064948662 [4441'01"N, 76³1'05"W]; very abundant around the edge of a cattail marsh; E. R. Thomson, 17 September 2003 (DAO 792124)

4. Frontenac County, Bedford District, west of Wolfe Lake, Briggs Lane, UTM: 18T 03788434948442 [44 $40 ' 53^{\prime \prime N}$, $76^{\circ} 31^{\prime} 42^{\prime \prime} \mathrm{W}$; thickly covering a shallow pond; mostly W. brasiliensis with some W. columbiana and a few W. borealis; E. R. Thomson, 24 September 2003 (DAO 792121)

5. Lanark County, south of Christie Lake on Althorpe Road, 200 yards west of Hanna Road, UTM: $18 \mathrm{~T} 0385598$ 4959533 [4446'56"N, 76²6'43"W]; cattail marsh / pond; E. R. Thomson, 26 September 2003 (DAO 792122)

6. Frontenac County, Bedford District, west of Wolfe Lake, UTM: 18T 03798744949264 [444ㄴ'16"N, 76³0'52"W]; small patches of open water in an old beaver wetland of grasses, sedges and holly; E. R. Thomson, 26 September 2003 (DAO 792120)

7. Frontenac County, Bedford District, west of Wolfe Lake, UTM: 18T 03803684950143 [4441'46"N, 76³0'33"W]; shallow old beaver pond; mostly sterile fronds, a few fertile fronds; E. R. Thomson, 16 October 2003 (DAO 792258) 